Natalia Shlikhta. Istoriia radianskoho suspilstva: Kurs lektsii. Kharkiv: Akta, 2015.

Reviewed by: Maria Melenchuk

Source: Kyiv-Mohyla Humanities Journal 3 (2016): 227-229

Published by: National University of Kyiv-Mohyla Academy

http://kmhj.ukma.edu.ua/ 


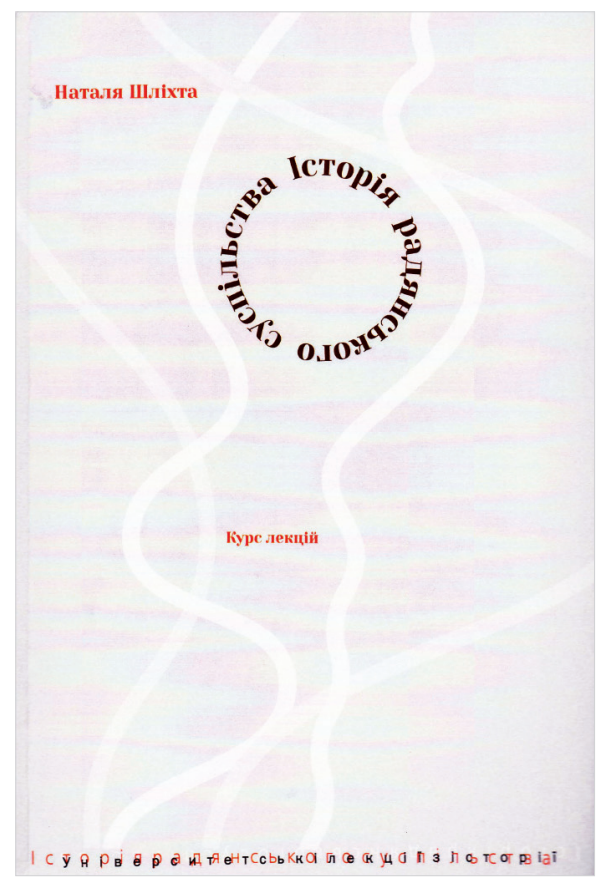

\title{
Natalia Shlikhta
}

\section{Istoriia radianskoho suspilstva: Kurs lektsii}

\author{
[The History of Soviet Society: \\ A Course of Lectures].
}

Kharkiv: Akta, 2015. 252 pp.

In Ukrainian.

ISBN 978-966-2410-55-6

\section{Reviewed by Maria Melenchuk}

What comes to mind when we hear the term "the Soviet Union"? Most people probably think about political leaders such as Lenin and Stalin, or about political terms like the Communist Party, socialist republics, the Soviet bloc, totalitarianism, or the Iron Curtain. In her book Istoriia radianskoho suspilstva: Kurs lektsii [The History of Soviet Society: A Course of Lectures], Natalia Shlikhta invites readers to consider more unusual and interesting pages of Soviet history: she offers an anthropological perspective on the history of Soviet society. Contemporary Ukrainian historiography is dominated by the political approach to writing about Soviet times. Although an interest in "everyday life" is beginning to develop, it still remains fragmented and incomplete. Shlikhta's book is a successful attempt to fill this gap. It is an excellent resource for students and educators who want to look at Soviet society through an anthropological lens.

Natalia Shlikhta is an Associate Professor and the Chair of the History Department at the National University of Kyiv-Mohyla Academy. She is a well-known researcher of church history under Soviet rule and a specialist in the anthropological history of Soviet society. The reviewed work is the product and summation of eleven years of her teaching at NaUKMA.

As Shlikhta indicates in the introductory chapter, her book is designed to assist professors and university students who teach and study the history of Soviet society; it is not intended as a comprehensive textbook on the subject, but rather as the opening of a conversation about certain aspects of Soviet social history. Even though her book is devoted to non-political facets of life, Shlikhta recognizes that every aspect of life in the Soviet state was, in one way or another, political. She argues the importance of examining "everyday life": the experiences, actions, and habits of ordinary people. Firstly, "everyday life" is a legitimate object of historical inquiry itself. Secondly, only such a perspective allows researchers to examine the real extent to which the Soviet state was able to achieve its political strategies.

In her book, Shlikhta argues that although the Soviet state dictated everyday norms in its attempts to construct a socialist state, many tactics of hidden resistance and opposition found 
currency in the daily lives of Soviet people. In other words, even though society was more or less under state control, it never transformed into the ideal socialist society that Soviet leaders envisaged. Shlikhta effectively develops and supports this main argument throughout the book.

Chronologically, the book embraces the period from the 1920s to the 1980s, allowing readers to trace the development of various aspects of social life during this time. The book consists of four chapters which organically complement each other. In Chapter 1, Shlikhta explains the terms "historical anthropology" and "Sovietology" and how they have evolved in Western and post-Soviet Russian and Ukrainian historiographies. Chapter 2 is devoted to the concept of Soviet identity and the Soviet policy of constructing "a Soviet man." Shlikhta describes different tools used by the Soviet state to create that desired ideal, such as the system of public education, atheism, the mass media, invented Soviet language, films, literature, sports, the work environment, and holidays. Chapter 3 is perhaps the most interesting part of the book. Here, the social structure of Soviet society is analyzed and great attention is paid to the everyday aspects of life under Soviet rule: shortages, queues at stores, social security, communal living, the concept of family, and the role of women. Readers will also find interesting information about leisure pastimes: movies, television, music, literature, and tourism. The author explains how the Soviet state tried to control even these, non-political, aspects of its citizens' lives. Private life and leisure time had to be socialized because they played a significant role in creating "the new Soviet man." Finally, the closing chapter addresses the misconception that non-conformism in the Soviet Union had only an open and political nature. It asserts that even such a totalitarian state as the Soviet Union was not able to exercise utter control over the lives of its citizens. Concealed everyday resistance was actually more sizable than the dissident movement. Shlikhta analyses various tools of everyday resistance used by different social groups. By examining the Russian Orthodox Church and religious life in Western Ukraine, she comes to the conclusion that despite the efforts to oust the Ukrainian Greek Catholic Church and subject Greek Catholics to the authority of the Moscow Patriarchate, West Ukrainian dioceses and the Ukrainian Exarchate were able to keep the distinctiveness of their denomination and maintain their autonomy to a certain degree.

Overall, this book is an example of scrupulous writing, which effectively accomplishes its purpose. Throughout the book, information is kept brief and precise with additional information placed inside notes. Each chapter contains theoretical and methodological concepts related to the topic discussed, such as historical anthropology, identity, class, and everyday resistance. Chapters end with conclusions and questions for self-testing or discussion. Readers will find an extensive list of primary and secondary sources on the discussed topics. Together, these features make Shlikhta's book an effective learning tool for students of Soviet history.

At the same time, a critical reader may find a few shortcomings in the book. For example, except for the question concerning religious life in Western Ukraine, regional differences in religion across Soviet republics are not considered. The geographical framework of topics discussed in the book is not clarified by the author. As a result, conclusions made seem too generalized. For some readers, the information as it is presented may seem somewhat tedious. However, it must be kept in mind that the book was written for readers with some knowledge of modern history. In all, despite such minor drawbacks, this textbook can effectively assist students in learning Soviet history. 
In conclusion, Shlikhta's book provides a valuable and absorbing window into the everyday lives of Soviet citizens - something that has been inaccessible to Ukrainian students for a long time. Besides being an effective learning tool, it can also serve as a starting point for further anthropological research into Soviet history. 